\title{
A Review on Recombinant Tissue Plasminogen Activator: In Vitro Synthesis and Its Use in Treatment of Acute Ischemic Stroke
}

\author{
Prabhu Sukumaran*, Eldho K. Poulse \\ Department of Biotechnology, Sri Venkateswara College of Engineering, Sriperumbudur, India \\ Email: ${ }^{*}$ sprabhu@svce.ac.in
}

Received 1 May 2014; revised 4 June 2014; accepted 16 June 2014

Copyright (C) 2014 by authors and OALib.

This work is licensed under the Creative Commons Attribution International License (CC BY). http://creativecommons.org/licenses/by/4.0/

(c) (i) Open Access

\begin{abstract}
Tissue-type Plasminogen Activator (tPA) is a serine protease produced by endothelial cells. They target plasminogen, an inactive precursor of plasmin and convert the plasminogen into active plasmin, which degrades the fibrin component of thrombus to aid in dissolution of blood clots. Hence tPA is commonly used in treatment of acute Ischemic stroke in the form of recombinant tissue plasminogen activator (rtPA). rtPA is produced using recombinant technology from different types of vectors depending on the quantities required for the treatment of different diseases. Alteplase (intravenous rtPA) is the most common therapy drug used to treat ischemic strokes. This review gives an outline of the in vitro synthesis of rtPA and its usage in treatment of Acute Ischemic stroke.
\end{abstract}

\section{Keywords}

Recombinant Tissue Plasminogen Activator (rtPA), Thrombolytic Activity, Acute Ischemic Stroke, Alteplase

Subject Areas: Bioengineering, Genetics

\section{Introduction}

Tissue Plasminogen Activator (tPA) is a protein which acts on plasminogen. It is a $70 \mathrm{kDa}$ serine protease which

${ }^{*}$ Corresponding author.

How to cite this paper: Sukumaran, P. and Poulse, E.K. (2014) A Review on Recombinant Tissue Plasminogen Activator: In Vitro Synthesis and Its Use in Treatment of Acute Ischemic Stroke. Open Access Library Journal, 1: e603.

http://dx.doi.org/10.4236/oalib.1100603 
is considered to be the product of the endothelial cells that line the various parts of the vascular system [1]. tPA converts plasminogen, the inactive precursor into active plasmin, which subsequently degrades the fibrin component of thrombus to aid in dissolution of blood clots. It is due to this property of tPA that it is commonly used in treatment of stroke and makes it a "drug" that is generally administered to stroke patients in the form of Recombinant Tissue Plasminogen Activator (rtPA). rtPA is systemically administered in cases of acute myocardial infarction, acute ischemic stroke, and pulmonary embolism whereas in the cases of peripheral arterial thrombosis, it is administered directly to the site where clot is present via an arterial catheter.

A stroke generally occurs when there is a change in the blood flow pattern to the brain. This causes immediate loss of brain functions and activities which can lead to loss of speech, loss of understanding capability and improper functioning of body parts like hands and legs. The difference in blood flow pattern is either due to ischemia, which is lack of blood flow due to formation of blood clots, or due to haemorrhage, which is leakage of blood, because of which there is a loss of function in the affected part of the brain. If left untreated, stroke can cause permanent neurological damage and ultimately death. The treatment of ischemic stroke is brought about by administrating an anti-thrombolytic agent which is given to the affected patient as soon as possible.

Though use of tPA has been considered a feasible option in treating Ischemic stroke, it seems inefficient and non-feasible to produce tPA in an industrial scale for therapy. Hence, alternate rtPA synthesized in vitro is considered for treatment. This review tries to give a glance of the production of recombinant tissue plasminogen activator and its use in treating Ischemic stroke.

\section{Ischemic Stroke: The Global and Indian Scenario}

The WHO defines stroke as the rapid development of clinical signs and symptoms of a focal neurological disturbance lasting more than 24 hours or leading to death with no apparent cause other than vascular origin [2]. Ischemic strokes are caused cerebral thrombosis or embolism which is caused by hardening of arteries. In the case of thrombic stroke, a clot may form in an artery that is already very narrow while embolic stroke is caused by a clot that breaks off from another place in the blood vessels of the brain, or from some other part of the body, and travel up to the brain. Ischemic stroke can be majorly classified into the subtypes: lacunar, nonlacunar and cardioembolic.

Study estimates state that approximately 20 million people suffer from stroke out of which only 15 million survive [3]. Due to the fact that developed countries have effective screening, evaluation and therapies for stroke against the developing countries have led to high death rates in developing countries due to stroke. This fact can be proved by data which suggest that $85 \%$ of global deaths due to stroke are from developing countries [4]. Another shocking fact is that $50 \%-85 \%$ of all strokes come under Ischemic strokes [5]. There is very minimal documented data available on the prevalence and mortality rate associated to stroke in India. However, even the minimal data throws up alarming figures that need to be addressed immediately. The Indian National Commission on Macro-economics and Health estimates an increase in number of stroke cases in India from 1,081,480 in 2000 to 1,667,372 in 2015 with 12\% of cases occurring in people below 40 years of age [6]. Hence, these issues need to be addressed quickly.

As per the factsheets of South Asia Network for Chronic Disease, India currently has programs like WHO STEPS programme, INTERSTROKE, INSPIRE, PURE and National programme on prevention and control of cardiovascular diseases, diabetes and stroke, to address issues related to stroke in India [7]. Despite there being so many programs launched with the intend to curb deaths related to stroke, the prospects still remain bleak with an urgent need for the Government of India to step in and takes initiatives which show an intend to facilitate prevention, treatment and rehabilitation to decrease stroke related fatalities in India

The classic symptoms associated with stroke are acute inset of unilateral paralysis, speech impairment, gradual vision and memory loss with the person going into a coma and ultimately death. Quick thinking and therapy is required to save a person who has suffered an Ischemic stroke.

\section{Tissue Plasminogen Activator}

The Tissue Plasminogen Activator (tPA) is a $70 \mathrm{kDa}$ serine protease which has 527 amino acid residues that can double as a thrombolytic agent which can be used to dissolve blood clots effectively. Its expression is high in those regions which are in close contact to fibrin clots. Though tPA and urokinase type Plasminogen activator (uPA) are classified as Plasminogen Activators, tPA has more enhanced binding of fibrin to specific regulatory 
domains than uPA [8] [9]. The fibrin-tPA complex in turn has a high affinity for Plasminogen. Besides, tPA is also the more dominant form produced by cultured human endothelial cells [10]-[14]. The tPA molecule consists of four domains which are functionally different. These include an amino-terminal region called the finger domain, an epidermal growth factor (EGF-like) domain, two kringle domains which are the K1 domain and the $\mathrm{K} 2$ domain, and a serine protease region with the active-site residues. The K2 domain is mainly responsible for the high affinity of tPA for fibrin and its activation by fibrin, although finger and EGF domains also contribute to a certain extent to the affinity [15] [16].

The inactive enzyme precursor plasminogen undergoes proteolytic cleavage to form a two-chain structure plasmin, this cleavage is performed by the tPA with plasminogen binding to tPA and fibrin with high affinity. The receptors of Plasminogen are expressed and found on surface of the endothelial cells. The two main candidate plasminogen receptors are alpha-enolase and annexin-II which interact with plasminogen which in turn gets converted into plasmin. Plasmin has been found to have excellent enzymatic activity on the cell surface and it acts in two ways: by either directly catalyzes the breakdown of fibrin [17] molecules thereby dissolving the blood clot, or by indirectly acting on fibrin by the plasmin-dependent activation of few matrix-degrading proteases like pro-stromelysin and pro-collagenase [18] [19].

\section{Using rtPA in Ischemic Stroke Treatment}

The recommended diagnosis for stroke as per the American Heart Association are Electro Cardio Gram, chest $\mathrm{X}$-ray, complete blood count, platelet count, brain imaging, prothrombin and partial thromboplastin time, glucose levels and serum electrolytes.

Comparing to ECG and chest X-ray, the recombinant tissue plasminogen activators (r-tPAs) is FDA-approved for treatment of myocardial infarction with ST-elevation (STEMI) and acute ischemic stroke (AIS). RtPAS used for immediate treatment whereas ECG and other methods only used for diagnosis of stroke. rtPA has become widely considered standard of care in acute ischemic stroke, so long as the patient presents soon after the onset of stroke symptoms.

Hypertension has been proved to be the most powerful predictor for ischemic stroke while diabetes, age beyond 40 years and current smoking are also important indicators [20]. Hyperhomocysteinemia is another cause for ischemic stroke in both young and old people [21] [22].

Alteplase (intravenous rtPA) is the only thrombolytic agent approved by the US Food and Drug Administration as of date [23]. There are however newer agents like alteplase, pro-urokinase, reteplase, tenecteplase, desmoteplase that are being considered as alternate options though they are not approved for administration so, as of now the best treatment is to use alteplase [24]. The use of tissue plasminogen activator to treat Ischemic stroke is however a highly controversial subject with arguments that the use of the protein is a good solution for the problem as well as arguments that it can cause adverse effects if used for treatment. tPA, certain neurologists believe that its use has risks and lack of efficacy [25].

Though there are reports which suggest that tPA therapy increased the instances of development of intracerebral hemorrhages from $0.6 \%$ in placebo-treated patients to $6.4 \%$ in tPA-treated patients [26]. However these numbers are not as grave as it seems because these numbers are still negligible when compared to the number of lives saved and the numbers are also dependant on a number of cases where the rtPA was not administered in time as well as medical errors [27]. Thus the use of recombinant Tissue Plasminogen Activator is justified, arguably the best therapy and is safe to treat Ischemic stroke cases.

\section{In Vitro Synthesis of rtPA: An Overview of Available Methods}

The need for use of tissue plasminogen activator as a thrombolytic agent is quite large and hence there is a need to synthesize it in large quantities with good yield, efficiency, proper folding, ease of production sans any type of contamination and high purity. tPA was initially synthesised for therapeutic purposes using Bowes melanoma cells but the need for a reliable process and higher yield led to development of prokaryotic and eukaryotic cell to yield the recombinant tPA [28]. Escherichia coli due to its low production cost has been a favoured choice of organism for researchers all over [29] [30]. The first time human tPA was isolated was from E coli as a single chain serine protease consisting of 527 amino acids and Ser at the N-terminus [31]. But over the years it has been found that human IPA is most difficult to produce in $E$. coli due to complex challenges posed in obtaining a properly folded structure which has more than two disulfide bonds (17 disulfide bonds) [32]. 
A virus expression vector which affects insect cells like Baculovirus expression vector was chosen to produce active rtPA in insect cells. The expression however replicated only in alkaline conditions and hence does not replicate in human cells due to their acidic nature and had lesser glycosylation than the tPA produced in humans [33]. Saccharomyces cerevisiae was another candidate that was chosen for rtPA production. The yeast cells also showed problems with glycosylation and folding. Hence, it was also considered a poor option [34].

Chinese Hamster Ovary (CHO) cells are the preferred choice for production of rtPA in vitro. Tissue plasminogen activator (rtPA, Activase), in 1987 was the first recombinant therapeutic protein synthesised in CHO-a mammalian cell [35]. Though, a good produce is got from mammalian cells, their drawbacks include high cost of medium, high chances of contamination and high cost of purifying the product. These negative aspects of mammalian cells have led to scientists looking for alternative methods like using members from the Trypanosomatidae family of protozoans to produce rtPA and various other recombinant proteins [36]. However, it remains to be seen if they are effective and economically feasible for commercial production. The future prospective of in vitro synthesized rtPA would be in some cases of diseases that feature blood clots, such as pulmonary embolism, myocardial infarction, and stroke, in a medical treatment called thrombolysis.

\section{Conclusion}

Ischemic stroke is caused by accumulation of fat along artery walls in a blood vessel which connects to a part of the brain, formation of a blood clot which blocks a blood vessel. Tissue Plasminogen Activator is an important protein in the human body and plays a significant role in the dissolution of blood clot; this is helpful in treatment of Ischemic Stroke when it is administered within three hours before symptoms of the condition. The large scale production of tPA the protein is tedious and expensive, hence rtPA is synthesized in vitro by several techniques. Till date rtPA remains the most preferred drug for the treatment of Ischemic Stroke though it has numerous side effects associated with it like hemorrhage. Though there are certain controversies existing regarding use of rtPA, studies have comprehensively proved that the use of rtPA is safe and efficient. Hence, it can be suggested that using intravenous rtPA (Alteplase) is at present the most efficient therapy for Ischemic Stroke as the fears of adverse effects said to be caused are unfounded. Ischemic Strokes causes millions of deaths worldwide with India also accounting for a major share of the fatalities. Though there are many initiatives taken to prevent stroke related deaths in India, the prospect is not bright. Hence, it is imperative that newer and effective initiatives are taken by the Government of India to address the issue of stroke and its effective treatment to prevent deaths. This review is concluded with a hope that newer, lesser toxic and more efficient rtPA based thrombolytic agents are developed in the very near future and that they will be used to save many human lives.

\section{Acknowledgements}

The authors thank the Department and College for helping them to collect the reprints and utilization of internet facility from Department and college library.

\section{References}

[1] Levin, E.G., Santell, L. and Osborn, K.G. (1997) The Expression of Endothelial Tissue Plasminogen Activator in Vivo: A Function Defined by Vessel Size and Anatomic Location. Journal of Cell Science, 110, 139-148.

[2] World Health Organisation (2005) Preventing Chronic Diseases: A Vital Investment. Geneva.

[3] Dalal, P., Bhattacharjee, M., Vairale, J. and Bhat, P. (2007) UN Millenium Development Goals: Can We Halt the Stroke Epidemic in India? Annals of Indian Academy of Neurology, 10, 130-136. http://dx.doi.org/10.4103/0972-2327.34791

[4] Gupta, R., Joshi, P., Mohan, V., Reddy, S. and Yusuf, S. (2008) Epidemology and Causation of Coronary Heart Disease and Stroke in India. Heart, 94, 16-26. http://dx.doi.org/10.1136/hrt.2007.132951

[5] Feigin, V., Lawes, C., Bennet, D., Barker-Cello, S. and Parag, V. (2009) Worldwide Stroke Incidence and Early Case Fatality in 56 Population Based Studies: A Systemic Review. The Lancet Neurology, 8, 355-369. http://dx.doi.org/10.1016/S1474-4422(09)70025-0

[6] Shah, B. and Mathur, P. (2006) Workshop Report on Stroke Surveillance in India. Division of Noncommunicable Diseases, Indian Council of Medical Research, New Delhi.

[7] Taylor, F.C. (2012) Stroke in India, South Asia Network for Chronic Disease Fact Sheets http://www.sancd.org/. http://sancd.org/uploads/pdf/factsheet_Stroke.pdf 
[8] Hoylaerts, M., Rijken, D.C., Lijnen, H.R. and Collen, D. (1982) Kinetics of the Activation of Plasminogen by Human Plasminogen Activator. Role of Fibrin. The Journal of Biological Chemistry, 257, 2912-2919.

[9] Ranby, M. (1982) Studies on Kinetics of Plasminogen Activation by Tissue Plasminogen Activator. Biochimica et Biophysica Acta (BBA), 704, 461-446. http://dx.doi.org/10.1016/0167-4838(82)90068-1

[10] Kristensen, P., Larsson, L.-I., Nielsen, L.S., Grondahl-Hansen, J., Andreasen, P.A. and Dano, K. (1984) Human Endothelial Cells Contain One Type of Plasminogen Activator. FEBS Letters, 168, 33-37. http://dx.doi.org/10.1016/0014-5793(84)80201-X

[11] Saksela, O., Moscatelli, D., Sommer, A. and Rifkin, D.B. (1988) Endothelial Cell-Derived Heparan Sulfate Binds Basic Fibroblast Growth Factor and Protects It from Proteolytic Degradation. The Journal of Cell Biology, 107, 743-751. http://dx.doi.org/10.1083/jcb.107.2.743

[12] Levin, E.G. and Loskutoff, D.K. (1982) Cultured Bovine Endothelial Cells Produce Both Urokinase and Tissue-Type Plasminogen Activators. The Journal of Cell Biology, 94, 631-636. http://dx.doi.org/10.1083/jcb.94.3.631

[13] Speiser, W., Anders, E., Preissner, K.T., Wagner, O. and Muller-Berghaus, G. (1987) Differences in Coagulant and Fibrinolytic Activities of Cultured Human Endothelial Cells Derived from Omental Tissue Microvessels and Umbilical Veins. Blood, 69, 964-967.

[14] Wojta, J., Jones, R.L., Binder, B.R. and Hoover, R.L. (1988) Reduction in P02 Decreases the Fibrinolytic Potential of Cultured Bovine Endothelial Cells Derived from Pulmonary Arteries and Lung Microvasculature. Blood, 71, 17031706.

[15] Van Zonneveld, A.J., Veerman, H. and Pannekoek, H. (1986) Autonomous Functions of Structural Domains on Human Tissue-Type Plasminogen Activator. Proceedings of the National Academy of Sciences of the United States of America, 83, 4670-4674. http://dx.doi.org/10.1073/pnas.83.13.4670

[16] Van Zonneveld, A.J., Veerman, H. and Pannekoek, H. (1986) The Interaction of the Finger and the Kringle-2 Domain of Tissue-Type Plasminogen Activator with Fibrin: Inhibition of Kringle-2 Binding to Fibrin by Epsilon-Amino Caproic Acid. Journal of Biological Chemistry, 261, 14214-14218.

[17] Dudek, G.A., Kloczewiak, M., Budzyński, A.Z., Latallo, Z.S. and Kopeć, M. (1970) Characterisation and Comparison of Macromolecular End Products of Fibrinogen and Fibrin Proteolysis by Plasmin. Biochimica et Biophysica Acta (BBA), Protein Structure, 214, 44-51. http://dx.doi.org/10.1016/0005-2795(70)90068-1

[18] Corcoran, M.L., Hewitt, R.E., Kleiner Jr., D.E. and Stetler-Stevenson, W.G. (1996) MMP-2: Expression, Activation and Inhibition. Enzyme Protein, 49, 7-19.

[19] Keski-Oja, J., Lohi, J., Tuuttila, A., Tryggvason, K. and Vartio, T. (1992) Proteolytic Processing of the 72,000-Da Type IV Collagenase by Urokinase Plasminogen Activator. Experimental Cell Research, 202, 471-476. http://dx.doi.org/10.1016/0014-4827(92)90101-D

[20] Ohira, T., Shahar, E., Chambless, L.E., Rosamond W.D., Mosley Jr., T.H. and Folsom, A.R. (2006) Risk Factors for Ischemic Stroke Subtypes: The Atherosclerosis Risk in Communities Study. Stroke, 37, 2493-2498. http://dx.doi.org/10.1161/01.STR.0000239694.19359.88

[21] Arrastia, R.D. (2000) Homocysteine and Neurologic Disease. Archives of Neurology, 57, 1422-1426.

[22] Modi, M., Prabhakar, S., Majumdar, S., Khullar, M., Lal, V. and Das, C.P. (2005) Hyperhomocysteinemia as a Risk Factor for Ischemic Stroke: An Indian Scenario. Neurology India, 53, 297-301. http://dx.doi.org/10.4103/0028-3886.16927

[23] (2005) Activase (Alteplase) Product Information. Genentech, South San Fransisco.

[24] Frendl, A. and Csiba, L. (2011) Pharmacological and Non-Pharmacological Recanalization Strategies in Acute Ischemic Stroke. Frontiers in Neurology, 2, 00032. http://dx.doi.org/10.3389/fneur.2011.00032

[25] Brown, D.L., Barsan, W.G., Lisabeth, L.D., Galler, M.E. and Morgenstern, L.B. (2005) Survey of Emergency Physicians about Recombinant Tissue Plasminogen Activator for Acute Ischemic Stroke. Annals of Emergency Medicine, 46, 56-60. http://dx.doi.org/10.1016/j.annemergmed.2004.12.025

[26] The National Institute of Neurological Disorders and Stroke rt-PA Stroke Study Group (1995) Tissue Plasminogen Activator for Acute Ischemic Stroke. The New England Journal of Medicine, 333, 1581-1587. http://dx.doi.org/10.1056/NEJM199512143332401

[27] Liang, B.A., Lew, R. and Zivin, J.A. (2008) Review of Tissue Plasminogen Activator, Ischemic Stroke, and Potential Legal Issues. Archives of Neurology, 65, 1429-1433.

[28] Griffiths, J.B. and Electricwala, A. (1987) Production of Tissue Plasminogen Activators from Animal Cells. Advances in Biochemical Engineering/Biotechnology, 34, 147-166.

[29] Sarmientos, P., Duchesne, M., Denèfle, P., Boiziau, J., Fromage, N., Delporte, N., Parker, F., Lelièvre, Y., Mayaux, J.F. and Cartwright, T. (1989) Synthesis and Purification of Active Human Tissue Plasminogen Activator from Escheri- 
chia coli. Nature Biotechnology, 7, 495-501. http://dx.doi.org/10.1038/nbt0589-495

[30] Qui, J., Swartz, J.R. and Georgiou, G. (1998) Expression of Active Human Tissue-Type Plasminogen Activator in Escherichia coli. Applied and Environmental Microbiology, 64, 4891-4896.

[31] Pennica, D., Holmes, W.E., Kohr, W.J., Harkins, R.N., Vehar, G.A., Ward, C.A., Bennett, W.F., Yelverton, E., Seeburg, P.H., Heyneker, H.L., Goeddel, D.V. and Collen, D. (1983) Cloning and Expression of Human Tissue-Type Plasminogen Activator cDNA in E. coli. Nature, 301, 214-221. http://dx.doi.org/10.1038/301214a0

[32] de Vos, A.M., Ultsch, M.H., Kelley, R.F., Padmanabhan, K., Tulinsky, A., Westbrook, M.L. and Kossiakoff, A.A. (1992) Crystal Structure of the Kringle 2 Domain of Tissue Plasminogen Activator at 2.4-.ANG Resolution. Biochemistry, 31, 270-279. http://dx.doi.org/10.1021/bi00116a037

[33] Furlong, A.M., Thomsen, D.R., Marotti, K.R., Post, L.E. and Sharma, S.K. (1988) Active Human Tissue Plasminogen Activator Secreted from Insect Cells Using a Baculovirus Vector. Biotechnology and Applied Biochemistry, 10, 454464.

[34] Ogrydziak, D.M. (1993) Yeast Extracellular Proteases. Critical Reviews in Biotechnology, 13, 1-55. http://dx.doi.org/10.3109/07388559309069197

[35] Lubiniecki, A., Arathoon, R., Polastri, G., Thomas, J., Wiebe, M., Garnick, R., Jones, A., van Reis, R. and Builder, S. (1990) Selected Strategies for Manufacture and Control of Recombinant Tissue Plasminogen Activator Prepared from Cell Culture. In: Spier, R.E., Griffiths, J.B., Stephenne, J. and Crooy, P.J., Eds., Advances in Animal Cell Biology and Technology for Bioprocesses, Butterworths, London, 442-451.

[36] Soleimani, M., Mahboudi, F., Davoudi, N., Amanzadeh, A., Azizi, M., Adeli, A., Rastegar, H., Barkhordari, F. and Mohajer-Maghari, B. (2007) Expression of Human Tissue Plasminogen Activator in the Trypanosomatid Protozoan Leishmania tarentolae. Biotechnology and Applied Biochemistry, 48, 55-61. http://dx.doi.org/10.1042/BA20060217 